\title{
Exploring Literacy Coach Research in Canada: A Review
}

\author{
PENG LIU \\ University of Manitoba \\ XUYANG LI \\ University of Manitoba \\ ZHUOMA CIREN \\ University of Manitoba
}

\begin{abstract}
The purpose of this review is to understand literacy coach research in Canada in order to facilitate further research in this regard. Research about literacy coaches in Canada remains at an initial stage, and there is no universally accepted definition of a "literacy coach." Most literacy coach research in Canada has used a qualitative method. The research has shown that literacy coaches in Canada, who act as both guides and supporters in schools, also experience many challenges such as role confusion and inadequate time for carrying out their work. Scholars believe that setting up coaching models and collaboration may be ideal ways to deal with these problems. This review also found that the research has concentrated on literacy coaches in elementary and secondary schools in Ontario. This article concludes with implications and suggestions for future research about Canadian literacy coaches. More analysis about literacy coaches' identity, their relationships with other stakeholders in the education system, and the challenges they face is needed in the Canadian context.
\end{abstract}

Keywords

literacy coach, research, Canada, literature review

\section{Introduction}

A literacy coach is broadly defined as a teacher with literacy expertise who works collaboratively with classroom teachers, administrators, and their school board. Literacy coaching is not a new concept in education, but it has become more and more popular in North America since the implementation of the No Child Left Behind Act (Elish-Piper \& L'Allier, 2010). Importantly, literacy coaches have become vital players in school management, particularly in the United States and Canada (Ferguson, 2013; Lockwood et al., 2010). Coaching is considered one effective way for schools to cope with challenges (Deussen et al., 2007). While coaching exists in many areas, it is most popular in literacy instruction (Deussen et al., 2007). Literacy coaches support classroom teachers' literacy instruction through coaching and leadership, so as to achieve better student learning outcomes (Bean \& Isler, 2008; Eastern School District, 2009; International Reading Association, 2004; Malavasic, 2020; Robertson et al., 2020; Symonds, 2003; Walpole \& McKenna, 2013). Researchers believe that literacy coaches have a positive influence on both school management and classroom instruction (Bean et al., 2007; Killion \& Harrison, 
2006; Lockwood et al., 2010; Rainville \& Jones, 2008; Sandvold \& Baxter, 2008; Walpole \& McKenna, 2004). Literacy coaches, who are beneficial for ongoing teacher learning, may foster teacher collaboration, improve instructors' teaching strategies, and enhance interaction between teachers through modeling teaching practices and reflecting on students' learning experience (Bean et al., 2003; Elish-Piper \& L'Allier, 2010; Ferguson, 2014a; Moore, 2010). In addition, literacy coaches are crucial to building teachers' selfconfidence and positive collegial relationships (Toll, 2005). Moreover, literacy coaches may assist school leaders in making coaching plans for teacher development and conducting new initiatives, which may be helpful for enhancing school effectiveness (Neufeld \& Roper, 2003; Shanklin, 2006). Studies about literacy coaches in Canada date back to the early 2000s, when the title of "lead literacy teachers" appeared in a report from the Ontario Ministry of Education called Early Reading Strategy: The Report of the Expert Panel on Early Reading in Ontario (Government of Ontario, 2003). According to Lynch and Ferguson (2010), studies about literacy coaches in Canada have been limited, although it is very important for school staff to understand the role of literacy coaches in Canada. In particular, there has been little holistic mapping of the development patterns of literacy coach research in Canada, which could facilitate further research in this regard. Therefore, it is essential to understand the current situation of the study of literacy coaches in Canada. This review investigated literacy coach research in Canada since 2000, based on the following research questions:

- How is the literature about literacy coaching distributed in terms of the kinds of articles that have been published in Canada (e.g., non-empirical, empirical, review) since 2000 ?

- What have been the topical foci of articles by scholars studying literacy coaching in Canada?

- What methodological preferences are evident in the scholarship on literacy coaching in Canada?

- What does the pattern of the citation impact of publications reveal about knowledge accumulation in Canada on literacy coaching?

This article will first describe the data sources included in the review. Then, the results of the analysis will be reported, starting with an explanation of the origin of literacy coaching in North America and alternative titles that have been used to refer to literacy coaches within the body of literature examined by this review. The names of the journals included in the review will be listed because their quality will be analyzed later. Then, the articles in the reviewed body of literature will be examined based on their publication year; their location; whether they are empirical, non-empirical, or a review; their focal topics; their research methodology; and their citation impact. This analysis will reveal patterns in the evolution of literacy coach scholarship in Canada. Finally, suggestions for future research about Canadian literacy coaches will be provided.

\section{Data Sources and Analysis Method}

To identify the literature to include in this review, a literature search was performed using all the terms that might refer to literacy coaches as key words combined with "Canada" and the name of each Canadian province and territory. This search located research articles, federal/provincial government documents, and program information 
related to the topic of literacy coaching. The following terms have been used to refer to literacy coaches in the literature: literacy coach, literacy instruction coach, literacy lead teacher, lead reading teacher, reading coach, literacy specialist, literacy mentor, literacy leader, literacy facilitator, resource teacher, reading specialist, and literacy intervention/support teacher. After all the available sources about Canadian literacy coaches were collected, the final step was to delete articles describing studies that were not conducted in a Canadian context, since a few of the identified articles were written about literacy coaching in Australia and the United States rather than in Canada.

The literature analyzed in this article included all the available sources that were relevant to literacy coaching in Canadian contexts. The sources included peer-reviewed journal articles, book chapters, doctoral or master's theses, conference reports, program reports, online magazines, and information from non-government organizations. In total, 17 articles and 12 other sources related to literacy initiatives of various sorts were found.

In terms of empirical studies, 10 of the articles included in this study were published in various educational journals, including the Canadian Journal of Education, California Reading, Reading Horizons, the Alberta Journal of Educational Research, Antistasis, Teaching and Teacher Education, Orbit, the Journal of Research in Rural Education, Teaching Education, and the Canadian Journal of Educational Administration and Policy. Two sources describing empirical studies were chapters from two books: the 60th Yearbook of the Literacy Research Association and Literacy Teacher Educators: Preparing Teachers for a Changing World. One $\mathrm{PhD}$ thesis and two unpublished master's theses about Canadian literacy coaches were identified from the University of Toronto, the University of Windsor, and the University of Manitoba respectively. In addition, one article about studies conducted in New Brunswick in an online magazine published by the EdCan Network was identified, and a conference report about the family literacy program in Newfoundland and Labrador from October 2000 was found. Finally, alongside the above empirical literature, literature related to 12 literacy initiatives that were funded by either provincial governments or the federal government were included. Formal analysis was conducted based on the four research questions through constant comparative analysis. The coding was stated at the lower level. For instance, "Support educator" was initially coded as "C3," where the letter " C" represents the theme "Literacy coaches' roles and responsibilities" and the number " 3 " represents the specific "roles and responsibilities." This code was combined with other codes after comparison to form the theme called "roles and responsibilities." This was the coding process used in this review.

\section{Findings}

\section{The Nature of the Studies on Literacy Coaching Reported in Articles Published in Canada}

Informed by Hallinger and Chen's (2015) comparative analysis, articles identified in this review were classified as empirical research, non-empirical research, or reviews to scrutinize them more closely.

Empirical research has played a significant role in the Canadian literature pertaining to literacy coaches. Among the 17 identified articles, 14 articles were about empirical research; they all involved data collection and analysis, and interviews were the most 
popular choice of data collection process. For example, Lynch and Ferguson (2010) interviewed a few literacy coaches working in Ontario elementary schools (at the primary, or K-3 level and the junior, or 4-6 level) and analyzed these literacy coaches' perceptions about their roles and accountability. This research was a typical empirical study. Moreover, Porter and AuCoin (2013) conducted a study in which resource teachers filled in a form concerning their daily activities such as working with instructors, making plans, classroom organization, and teacher conferences. One common feature of these studies was that their findings were connected with the results of surveys completed by participants.

Besides empirical research, reviews accounted for the rest of the literature. Three articles were identified as reviews. One was classified as a review because it offered five practical research-based tips for literacy coaches that were derived by synthesizing the published literature on literacy coaching in North America. However, this article summarized the findings of this literature generally and offered suggestions without referring specifically to the review data. One conference report and one program report were also classified as reviews. They both introduced how literacy coaches took on their roles in their respective programs. For example, the program report, which was about literacy coaches in Ontario, explored how teachers can assist students with learning difficulties and ways to motivate students in the classroom (Government of Ontario, 2003). This report presented a systematic review of literacy coaching for the early years. The review began with background information about reading development in Ontario, and then analyzed what an expert panel on early reading was able to do to improve instruction at school. This report is a classic document that many schools in Ontario use to guide their school organizations.

Given the fact that only 14 empirical research studies on literacy coaches were identified in the Canadian context since 2000, this small number of articles is not yet ready for comparative analysis. The fact that this review identified only one review-type article (plus two relevant reports), therefore, is understandable. Surprisingly, this review identified no non-empirical research articles on literacy coaches in Canada. This may be due to the fact that the position of literacy coach is rooted in the peer coaching model for professional development in North America instead of being studied using a theoretical framework.

\section{Focal Topics of Research on Literacy Coaching in Canada}

It is worthwhile examining literacy coaching as a research topic as this examination allows readers to see how this topic has evolved in Canada geographically and over time and what aspects of literacy coaching have attracted scholars' interest the most. Therefore, in addition to showing the general trend of focal topics, publication dates and locations were analyzed to understand more about the development of literacy coach scholarship in Canada.

Six focal topics were identified in the Canadian literature: literacy coaches' roles and responsibilities (36\%), suggestions and tips for literacy coaches (21\%), literacy coaches' education and training (15\%), barriers and challenges that literacy coaches face $(10 \%)$, literacy coaches' understanding and perceptions $(10 \%)$, and literacy coaches' identity and relationships with other stakeholders (8\%) (see Figure 3). 
Literacy coaches' roles and responsibilities. Researchers have placed much of their attention on exploring literacy coaches' roles and responsibilities (Ferguson, 2013; Luu, 2020). All the Canadian literature has regarded literacy coaches as guides and supporters in the classroom. To be specific, scholars have agreed that taking on the literacy coach role means assisting teachers with instructional strategies, professional development, and resource management in order to improve students' literacy development (Ferguson, 2013). Literacy coaches undertake many activities to accomplish their tasks. As a guide, a literacy coach may offer directions for classroom instruction and lead the teaching community. As a supporter, a literacy coach is able to offer content knowledge and student information that may be beneficial for both school administrators and instructors. However, there are still some debates about literacy coaches' roles and responsibilities. Seven out of 17 articles mentioned that Canadian literacy coaches suffer from role confusion. In other words, literacy coaches are not aware of what they are expected to do to help teachers (Porter \& AuCoin, 2013). In addition, three articles or program documents maintained that there should be goals and expectations for literacy coaches. The literacy coaches' roles and responsibilities should be connected with such expectations, but, in the Canadian school system, the expectations and goals are not very clear for literacy coaches. Luu (2020) claimed that instructional coaches are not fully prepared for their roles and responsibilities in their daily work, although literacy coaches support educators on many levels such as facilitating professional learning, providing resources, collaborating on school improvement planning, and giving training to other colleagues. In this line of research, it will be meaningful to further explore the antecedents of role ambiguity and its effects and also specify the leadership and coaching practices used by literacy coaches in the Canadian school context.

Barriers and challenges that literacy coaches face. The challenges and barriers facing literacy coaches in Canada have been another focus in the literature. These difficulties may be caused by poor management within a school system. In addition to literacy coaches' main outlined responsibilities, researchers have observed that literacy coaches may also have to perform organizational tasks at the school level (Ferguson, 2013) and other undefined duties (Manitoba Education and Advanced Learning, 2014). As a result, research interest has focused on the challenges and barriers that literacy coaches face, such as role ambiguity, teacher resistance, limited principal involvement (Lynch \& Ferguson, 2010), communication issues (Luu, 2020), time allocation issues (Porter \& AuCoin, 2013), and inadequate training (Society for the Advancement of Excellence in Education, 2009). Among these barriers and challenges, the time allocation issue may be the most obvious one. Eight articles and program documents argued that it is very time-consuming to be a literacy coach in Canada. Literacy coaches are expected to do a great number of tasks within a limited time. Some literacy coaches believe that they have too many schools to serve during a single time period, and that this has caused these literacy coaches to lack the preparation time necessary to support teachers. Furthermore, seven studies and program documents concluded that the changes that literacy coaches may face are likely to be challenging for them (Bartlett, 2017; Canadian Institute of Reading Recovery, 2018; Ferguson, 2013; Fougere, 2014; Hibbert et al., 2008; Jamieson, 2009; Kelly \& Cherkowski, 2015). There were also some other 
challenges and barriers for literacy coaches in Canada that were only mentioned by a single article, including low income, reduced achievement, limited resource materials, and principals' poor administrative ability. Future research might focus on the effects of these challenges and administrative strategies to cope with them in order to improve the effectiveness of literacy coaches.

Improvement of literacy coaches' performance. As for how to improve literacy coaches' performance, scholars have concentrated on the effectiveness of the coaching model and collaboration. About $70 \%$ of the Canadian literature about literacy coaches (19 articles and program documents) mentioned that a coaching model for both literacy coaches and instructors is essential to enhance the efficiency of coaching activities. In addition, 12 studies argued that literacy coaches should collaborate with their colleagues, such as school mentors and principals, and some of this literature also recommended student collaboration in the classroom (Bartlett, 2017; Canadian Institute of Reading Recovery, 2018; Ferguson, 2011; Ferguson, 2013; Ferguson, 2014a; Fougere, 2014; Hibbert et al., 2008; Kelly \& Cherbowski, 2015; Lynch \& Alsop, 2007; Lynch \& Ferguson, 2010; Manitoba Education and Advanced Learning, 2014; Moar, 2000). Only through collaboration can literacy coaches work more effectively. The forms of collaboration varied from school to school. Examples included establishing professional learning communities and building up turnaround teams. A turnaround team may consist of the literacy coach, the principals, the instructors, and other school administrators, but a learning community may also include students, so that the literacy coach and students are able to learn from each other. Further research on the roles of literacy coaches in the school turnaround process and administrative strategies to improve effectiveness are required.

Literacy coaches' understanding and perceptions. Scholars have also explored literacy coaches' understanding and perceptions about the process of becoming a literacy coach. These perceptions are also related to the barriers and challenges literacy coaches face. Literacy coaches may feel uncomfortable about their power and their role as change agents, and they may experience teacher resistance. Five studies mentioned that a literacy coach may experience teacher resistance, and four out of these five articles argued that literacy coaches were very uncomfortable about the top-down structure in the school system (Ferguson, 2014b; Fougere, 2014; Hibbert et al., 2008; Kelly \& Cherbowski, 2015). In other words, these literacy coaches felt that school administrators who wanted to control the literacy coaches in their schools instead of assisting them had too much power. The remaining article regarded the change that literacy coaches need to champion as the reason for teacher resistance. This line of research has lacked sufficient exploration of the effects of these perceptions through quantitative or qualitative research. Other topics such as the well-being of literacy coaches, who are affected by school conditions, need to be further explored.

Literacy coaches' relationship with other stakeholders. Literacy coaches' relationships with other stakeholders are connected with literacy coaches' roles and responsibilities. These relationships are of vital importance for school management, but 
the literature has not described a specific, widely accepted type of relationship between the literacy coach and other school staff. The most commonly described relationship has been a collaborative relationship. This review identified seven studies that explored the relationship between literacy coaches and other school staff (Ferguson, 2011; Fougere, 2014; Hibbert et al., 2008; Kelly, 2015; Lynch \& Alsop, 2007; Lynch \& Ferguson, 2010; Manitoba Education and Advanced Learning, 2014). In all of these articles, literacy coaches were considered the colleagues of other teachers. In one article, Ferguson (2011) described the relationship between literacy coaches and teachers as very informal and personal (like friends); she also believed that literacy coaches and principals worked as a team, which meant that their relationship was reciprocal and based on trust. However, this article was the only one that argued that literacy coaches and school managers had a great relationship. The other six studies mentioned that the school manager, such as the principal, was a controller rather than a partner. In these schools, the problem of hierarchy was very serious, and the literacy coaches did not have faith in their principals (Hibbert et al., 2008; Kelly \& Cherbowski, 2015; Lynch \& Alsop, 2007; Lynch \& Ferguson, 2010; Manitoba Education and Advanced Learning, 2014). These results show that many literacy coaches in Canada are not satisfied with their school management, and these literacy coaches may actually have terrible relationships with their school administrators. Further research on the relationship between coaches and teachers from leaders' and followers' perspectives would contribute to the understanding of this sophisticated relationship, and the effects and antecedents of this relationship need to be further explored.

There were some other notable characteristics featured in the literature. For example, the topic of the roles and responsibilities of literacy coaches appeared from 2000 to 2018 , covering much of the time period that was examined in this review. This topic also attracted attention from the largest number of provinces and territories (Ontario, Newfoundland and Labrador, News Brunswick, Nuvanut, PEI, Alberta, Manitoba, Yukon, BC, and Nova Scotia), many of which did not explore other topics. In general, regardless of time and location, scholars in Canada showed the highest level of interest in the topic of literacy coaches' roles and responsibilities. Suggestions and tips for literacy coaches made up the second most popular topic over time and in various locations across Canada. Research interest in the topic of literacy coaches' identity and relationships has steadily grown since 2011, but these studies have been conducted only in Ontario. Another trend is that most topics studied in the Canadian literacy coach literature have been related to literacy coaches' ultimate objectives, one of which is to achieve better student learning outcomes. Overall, although the focal topics have been classified into six types in this article, the topics have been interrelated and have not reached a wide scope.

\section{Research Methods Used in the Canadian Literature}

Analyzing research methods is another way to examine how knowledge production has been constructed in the field of literacy coaching. In this review, methodologies within the empirical research studies were classified as quantitative, qualitative, or action research. The application of these research methodologies in the literature is further explored below. 
Qualitative research methods have played a dominant role in the literature about literacy coaches in Canada. Scholars used a qualitative method in 10 out of the 14 (71\%) empirical studies examined in this review, and interviews were the most popular way to collect data. For instance, Fougere's (2014) study analyzed the relationship between coaches and coachees using sociocultural theory as a theoretical framework, and so a qualitative research method was the most suitable for getting to know stories about literacy coaches' instructional lives. It is noteworthy that most researchers have preferred a qualitative research method while studying Canadian literacy coaches for similar reasons. Through interviews, scholars have been able to understand the current situation of literacy coaches in the Canadian context. In addition, qualitative methods are essential in the grounded theory analysis process after learning about literacy coaches' experiences at school. Another example of this research methodology is Lynch and Ferguson's (2010) study, which collected data from literacy coaches who worked in an urban school in Ontario through interviews. In addition, Rowsell et al. (2008) interviewed and observed literacy coaches for about two years. While most of these qualitative studies used semistructured interviews, it is noteworthy that Fougere (2014) attempted to use a novel analytical method called Interpretative Phenomenological Analysis (IPA) to analyze data. This method aims to understand the psychological world via individual experience. Fougere (2014)'s study was the only one to use IPA to analyze data. Thus, in comparison with other studies regarding Canadian literacy coaches, Fougeres' (2014) findings are original.

Action research, a form of mixed method research, was used three times among the 14 articles $(21 \%)$. By contrast, scholars expressed little interest in employing quantitative methodology while exploring the topic of literacy coaching in a Canadian context; it only appeared once in the literature (7\%). Conversely, case study was popular as a qualitative methodology, making up $29 \%$ of all methodologies. The researchers enjoyed using interviews to collect data, and some researchers also used classroom observation. Based on this review, the qualitative research method has been the dominant one in Canadian literacy coach research. Quantitative research has the potential to deepen understanding of the effectiveness of literacy coaches. For instance, it could pinpoint the extent to which the leadership practices of literacy coaches can affect teachers' teaching practices and other variables relevant to teacher motivation and teacher emotions.

\section{Citation Impact of Relevant Publications in Canada}

Scholars have done a great deal of research about literacy coaches in Canada, but the influence of the various articles and research papers they have produced has been quite varied. This can be seen from the number of citations of each document. Some unpublished papers may have had limited influence due to the limited number of times these papers have been cited.

The impact factors of the journals included in this review could differ vastly as the articles in this review were not selected from predetermined journals at the outset of the study. Out of all the journals in which literature for this review was found, the Canadian Journal of Education and the Alberta Journal of Educational Research ranked fifth and ninth respectively among journals on education in Canada in 2018 (Scimago Institution Ranking, 2018). More findings associated with citation impact were obtained from the 
software program Publish or Perish, which retrieves and analyzes academic citations using Google Scholar as a database for raw citations and presents metrics such as citations per year, h-index value for journals, and the total citation numbers for individual articles (Harzing, 2007). The number of citations per year for the 10 journals in this review ranged from 1.65 for California Reading to 6,620.53 for Teaching and Teacher Education. These journals represented vastly different academic impacts from the perspective of evaluating a journal's quality through the number of citations it receives. Another method of evaluating journals, the h-index, offers a combined evaluation of journal quantity and quality. Teaching and Teacher Education, with an h-index of 239, could be considered an exceptional journal and made up $41 \%$ of the total h-index value yielded by all 10 journals in this review. (See Figure 4.)

In total the articles in this review yielded 343 citation counts with a range from 0 to 96 citations per article and a mean of 20.1 citations per article. Four articles had not been cited, namely Moar's (2000) unpublished master's thesis, Drake and Anonsen's (2000) conference report, Bartlett's (2017) article, and Porter and AuCoin's (2013) article that was published online. Conversely, Rowsell et al.'s (2008) and Lynch and Ferguson's (2010) articles had been cited 96 times and 66 times respectively, making up approximately half of the total citations received. As reported in the previous section, researchers' favorite topics regarding literacy coaching in Canada were the roles and responsibilities of literacy coaches and suggestions for assisting literacy coaches in Canada. The two articles mentioned above that had obtained about half the total number of citations were about approaches to teacher education for literacy coaching and the roles of literacy coaches. Thus, their citation impact was positively related to their topics. Furthermore, these two articles utilized a qualitative research method involving interviews. Previous research showed that a qualitative research method was preferred by most of the researchers conducting studies about Canadian literacy coaches, so these articles' citation impacts may also have been influenced by their methodology. As a limited number of journals and articles accounted for a large proportion of the total h-index value and citation numbers in the literature on literacy coaching in Canada, it is safe to conclude that this literature, as a whole, has had a limited impact on scholarship.

\section{Discussion and Conclusion}

This analytical review strived to ascertain the developmental patterns in the literature on literacy coaching in Canada so as to develop a better understanding of how such knowledge production has been generated and how it has been distributed in terms of time and location across Canada. For the purpose of achieving this goal, 17 articles and documents related to 12 programs were identified and analyzed. In addition to offering a synthesis of the findings, in this section, the limitations of this study and its implications for future research will be discussed.

It can be concluded from the literature that research on literacy coaching in Canada has not yet reached a mature developmental stage; a limited number of related research topics have been investigated in Canada compared with the United States, and the overall research productivity has been relatively low. This assertion is also evidenced by the fact that the literature has developed a limited number of themes; only six topics have been consistently examined in the literature. Among these topics, the roles and missions of 
Canadian literacy coaches as well as advice for helping literacy coaches were the focus of more than half of the identified literature, which indicates that the research area of literacy coaching in Canada remains very narrow. The Canadian literature has confirmed that role ambiguity is a common problem for literacy coaches across countries, but further research on the solutions to role ambiguity is in demand.

The Canadian literature also confirmed that lack of administrative support is a challenge faced by literacy coaches (Gross, 2012). Canadian research has expanded the understanding of the challenges literacy coaches face, which include time allocation, communication, limited resources, and principals' lack of ability. The challenge of time allocation means that Canadian literacy coaches lack sufficient time to conduct their work. Communication issues mainly refer to the clear passing of information to different stakeholders in the school organization. Clarity in communication will contribute to the effectiveness of literacy coaches' work. Furthermore, principals are some of the key people who can affect the work of literacy coaches because, as informal leaders, literacy coaches need support from principals to fulfil their responsibilities. Therefore, insufficient support and lack of ability on the part of school principals will affect the work of literacy coaches.

This study also identified that effective collaboration is vital for the success of literacy coaches. This is because literacy coaches need support from colleagues within their school community to provide effective coaching and leadership. This finding has been confirmed by international literature like Selvaggi (2016). Further research on how collaboration is structured and used in the work of literacy coaches needs further exploration.

Similar to the international literature, there has been no universal definition of a literacy coach in the Canadian literature. Researchers in Canada have often defined literacy coaches' roles from different perspectives, among which support for reading ability has been the most popular one. Literacy coaches also have gone by different titles in a number of Canadian articles and documents, which may cause confusion for future studies. Role ambiguity has been one focus in Canadian studies, which have aligned with international studies. Further research on the antecedent of role ambiguity and solutions to role ambiguity is highly needed for resolving practical problems in education.

The relationship between coaches and other stakeholders is an important issue in the Canadian context, as it is in the international literature. However, further exploration of how these relationships are built, developed, and used in educational practice will contribute the field, especially from comparative perspective across countries.

Knowledge production has been distributed unevenly: a majority of the articles and related programs examined in this study have been concentrated in Ontario, and no articles published before 2000 were identified. A reason for the lack of pre-2000 literature may be that literacy coaching is a new job in Canada, so it was not familiar to a wide range of Canadian researchers before 2000. The concentration of research in Ontario may be attributable to the fact that there are more students and post-secondary institutions in Ontario than in any other province in Canada, and therefore there is likely to be more researchers in Ontario. It is easier for these researchers to conduct research using face-toface interactions and classroom observation in Ontario. Furthermore, many studies have centered on literacy coaches in elementary and secondary schools in Ontario, but very little research has been conducted in adult education or at the post-secondary level. Still, Weir, 
and Goldblatt's (2007) introductory article about an adult literacy tutor in Alberta was one example of a study about literacy coaching in adult education. However, this article was just an introduction to a program rather than a research paper. Therefore, there has been a serious shortage of analysis about literacy coaching in the Canadian adult education context.

The uneven development of scholarship on Canadian literacy coaching has been manifested in the phenomenon of researchers showing a strong preference for both empirical studies over non-empirical or review studies and qualitative methodologies over quantitative or mixed-method methodologies. Empirical studies and qualitative research methods have dominated the literature about Canadian literacy coaching. This methodological preference can also be seen in the number of citations in the literature. Citation impact showed the uneven development of this body of literature; a few articles accounted for around half of the total citations, and the quality of the journals varied vastly. Moreover, citation impact was positively associated with the research methods used in the articles. Qualitative methodology dominated in the citation impact of the literature on literacy coaching in Canada.

Most of the research on Canadian literacy coaching has been based on data collected from practice in schools and classrooms. Certain scholars have studied the new topic of literacy coaches' identity and relationships using a theoretical framework. However, these theoretical studies remain in an immature phase. That being said, these studies that have explored literacy coaching in Canada using a theoretical approach have offered a new direction for literacy coach research.

The major limitations of this review arose from its incapacity to include literature written and disseminated in French. Given the fact that Canada is an officially bilingual country, the French literature has constituted an important part of its knowledge production on literacy coaching. In the province of Quebec, French is used more widely than English.

\section{Suggestions for Future Research}

It is obvious that the literature on literacy coaching in Canada displays an overall characteristic of sparse production. Firstly, the number of articles in this area has been low across Canada; only 17 articles and 12 program documents were identified in this review, which is low even if some articles may have been neglected due to this study's limitations. This review shows that there is an urgent need for conducting more studies related to literacy coaching in a Canadian context to obtain a richer understanding of this subject area. Furthermore, the focus of future studies on literacy coaching could move from the literacy coach's roles and duties to other topics so that a more comprehensive understanding of literacy coaching could be obtained. This would be beneficial not only for educators but also for students in Canada. Secondly, researchers have placed more emphasis on studies in the Ontario context, resulting in an uneven development pattern of knowledge production in Canada. This has especially been the case in Saskatchewan, where this review identified no studies. Therefore, there is an urgent need for more studies to be conducted in Canadian places other than Ontario. In addition, since the education system in Canada varies across different provinces and territories, a comparative study of literacy coaching in Ontario and in other parts of Canada might be helpful for those who do not understand literacy coaching in Canada. Moreover, adopting a quantitative 
methodology would be beneficial for adding layers to the existing knowledge base. Previous studies have included a lot of classroom observation and interaction research, and a different method might find some hidden facts about Canadian literacy coaches.

Finally, there should be a universal standard for both the typology of literacy coaches and the instructional coaching model (i.e., a universal definition of the role of a literacy coach). This standard is of very great importance for future research. The definition of literacy coaching should not concentrate only on reading but also on other aspects of literacy coaches' work that could serve as research areas. Previous researchers have done a lot of analysis of the existing literature using the titles "reading coach" and "reading specialist." Other types of literacy coaches who go by other titles are also worth exploring. In terms of the coaching model, researchers have noticed the functions of the model, but analyzing the model using a standard definition of literacy coaching could yield a deeper analysis. Such a standard might point to a direction for how to design and use the instructional model in the classroom.

\section{References}

Bartlett, A. K. (2017). Professional development, expectations, and coaching: One school's approach to strengthening balanced literacy instruction. Antistasis, 7(1), 104-114. https://journals.lib.unb.ca/index.php/antistasis/article/view/25158

Bean, R. M., \& Isler, W. (2008). The school board wants to know: Why literacy coaching? Literacy Coaching Clearinghouse. https://www.researchgate.net/publication/234669842_The_School_Board_Wants to_Know_Why_Literacy_Coaching

Bean, R. M., Jenkins, K., Belcastro, B., Wilson, E., Turner, G., \& Zigmond, N. (2007, November 28-December 1). What reading coaches do and why they do it: A diary study [Paper presentation]. National Reading Conference, Austin, TX.

Bean, R.M., Swan, A.L., \& Knaub, R. (2003). Reading specialist in schools with exemplary reading programs: Functional, versatile, and prepared. The Reading Teacher, 56(5), 446-455. https://www.jstor.org/stable/20205223?seq=1

Canadian Institute of Reading Recovery. (2018). Standards and guidelines ( $5^{\text {th }}$ ed.). http://rrcanada.org/wp-content/uploads/2018/02/CIRR-Standards-and-Guidelines5th-ed-final-draft_Feb2018.pdf

Deussen, T., Coskie, T., Robinson, L., \& Autio, E. (2007). “Coach” can mean many things: Five categories of literacy coaches in Reading First (REL 2007 No. 5). National Center for Educational Evaluation and Regional Assistance. https://ies.ed.gov/ncee/edlabs/regions/northwest/pdf/REL_2007005_sum.pdf

Drake, A., \& Anonsen, K. (2000). Gathering voices: Building an alliance for family literacy: Proceedings report. National Literacy Secretariat. http://en.copian.ca/library/research/voices/voices.pdf

Eastern School District. (2009). Annual report 2008-2009. https://www.nlesd.ca/about/annualreports/doc/archive/eastern/ar2008-09.pdf

Elish-Piper, L., \& L'Allier, S. K. (2010). Exploring the relationship between literacy coaching and student reading achievement in grades $\mathrm{K}-1$. Literacy Research and Instruction, 49(2), 162-174. https://doi.org/10.1080/19388070902913289 
Ferguson, K. (2011). Examining the relationships of power and resistance in literacy coaching in three school contexts. In P. J. Dunston, L. B. Gambrell, K. Headley, S. K. Fullerton, P. M. Stecker, V. R. Gillis, \& C. C. Bates (Eds.), 60th Yearbook of the Literacy Research Association (pp. 165-178). Literacy Research Association, Inc.

Ferguson, K. (2013). Exploring the role of literacy coaches: A case study of three schools in Ontario. Alberta Journal of Educational Research, 59(4), 535-552.

https://www.researchgate.net/publication/289652907_Exploring the_role_of_liter acy_coaches_A_case_study_of_three_schools_in_Ontario

Ferguson, K. (2014a). How three schools view the success of literacy coaching: Teachers', principals' and literacy coaches' perceived indicators of success. Reading Horizons: A Journal of Literacy and Language Arts, 53(1), 23-48. https://scholarworks.wmich.edu/reading horizons/vol53/iss 1/9

Ferguson, K. (2014b). Five practical research-based tips for literacy coaches. California Reader, 47(3), 27-34. https://www.researchgate.net/publication/319525034_Five_Practical_ResearchBased_Tips_for_Literacy_Coaches

Foucault, M. (1979). Discipline and punish: The birth of the prison. Vintage Books.

Fougere, D. M. E. (2014). Instructional coaching relationships: An interpretative phenomenological analysis [Master's thesis, University of Windsor]. Scholarship at UWindsor.

https://scholar.uwindsor.ca/cgi/viewcontent.cgi?article=6127\&context=etd

Government of Ontario. (2003). Early reading strategy. http://www.edu.gov.on.ca/eng/document/reports/reading/

Gross, P. A. (2012). Challenges of literacy coaching in high school. The Educational Forum, 76(2), 201-215. https://doi.org/10.1080/00131725.2011.652292

Hallinger, P., \& Chen, J. (2015). Review of research on educational leadership and management in Asia: A comparative analysis of research topics and methods, 1995-2012. Educational Management Administration \& Leadership, 43(1), 5-27. https://doi.org/10.1177/1741143214535744

Harzing, A.W. (2007). Publish or perish [Computer software]. https://harzing.com/resources/publish-or-perish

Hibbert, K. M., Heydon, R. M., \& Rich, S. J. (2008). Beacons of light, rays, or sun catchers? A case study of the positioning of literacy teachers and their knowledge in neoliberal times. Teaching and Teacher Education, 24(2), 303-315. https://doi.org/10.1016/j.tate.2007.01.014

International Reading Association. (2004). The role and qualifications of the reading coach in the United States. International Reading Association.

Jamieson, D. G. (2009). National strategy for early literacy. Canadian Language and Literacy Research Network. https://www.strongstart.ca/wpcontent/uploads/National-Strategy-for-Early-Literacy.pdf

Kelly, J., \& Cherkowski, S. (2015). Collaboration, collegiality, and collective reflection: A case study of professional development for teachers. Canadian Journal of Educational Administration and Policy, 169. https://files.eric.ed.gov/fulltext/EJ1063374.pdf 
Killion, J., \& Harrison, C. (2006). Taking the lead: New roles for teachers and schoolbased coaches. National Staff Development Council.

Lockwood, J. R., McCombs, J. S., \& Marsh, J. (2010). Linking reading coaches and student achievement: Evidence from Florida middle schools. Educational Evaluation and Policy Analysis, 32(3), 372-388. https://doi.org/10.3102/0162373710373388

Luu, K. N. (2020). Experiences, challenges and preparation of instructional coaches [Doctoral thesis, University of Toronto]. TSpace. https://hdl.handle.net/1807/103789

Lynch, J. \& Alsop, S. (2007). The effectiveness of literacy coaches (Research Monograph No. 6). Literacy and Numeracy Secretariat. http://citeseerx.ist.psu.edu/viewdoc/download?doi=10.1.1.495.5896\&rep=rep1\&t ype $=$ pdf

Lynch, J., \& Ferguson, K. (2010). Reflections of elementary school literacy coaches on practice: Roles and perspectives. Canadian Journal of Education, 33(1), 199-227. https://files.eric.ed.gov/fulltext/EJ883529.pdf

Malavasic, J.T. (2020). Collaborative learning communities in middle school literacy education: Increasing student engagement with authentic literacy. Routledge.

Manitoba Education and Advanced Learning. (2014). Supporting inclusive school: A handbook for resource teachers in Manitoba Schools.

https://www.edu.gov.mb.ca/k12/specedu/res_teacher/pdf/sis_resource_teachers mb_schools.pdf

Moar, C. L. (2000). Professional growth through journaling: A resource teacher's perspective on literacy learning [Master's thesis, University of Manitoba]. MSpace. https://mspace.lib.umanitoba.ca/handle/1993/2596

Moore, D.W. (2010). Creating state and national networks for adolescent literacy and coaching: An interview with Nancy L. Shanklin. Journal of Adolescent and Adult Literacy, 54(2), 142-144. https://www-jstororg.uml.idm.oclc.org/stable/20775369

Neufeld, B. \& Roper, D. (2003). Coaching: A strategy for developing instructional capacity: Promises and practicalities. The Aspen Institute Aspen Program on Education. https://assets.aspeninstitute.org/content/uploads/files/content/docs/pubs/Coaching _NeufeldRoper.pdf? ga=2.153875064.1197856702.15945093231014625308.1594509323

Porter, G. L., \& AuCoin, A. (2013). The role of the resource teacher in an inclusive setting: A time-use inquiry in New Brunswick schools.

https://www.edcan.ca/articles/the-role-of-the-resource-teacher-in-an-inclusivesetting/

Rainville, K. N., \& Jones, S. (2008). Situated identities: Power and positioning in the work of a literacy coach. The Reading Teacher, 61(6), 440-448. https://doi.org/10.1598/RT.61.6.1

Robertson, D. A., Padesky, L. B., Ford-Connors, E., \& Paratore, J. R. (2020). What does it mean to say coaching is rational? Journal of Literacy Research, 52(1), 55-78. https://doi.org/10.1177/1086296X19896632 
Rowsell, J., Kosnik, C., \& Beck, C. (2008). Fostering multiliteracies pedagogy through preservice teacher education. Teaching Education, 19(2), 109-122. https://doi.org/10.1080/10476210802040799

Sandvold, A., \& Baxter, M. (2008). The fundamentals of literacy coaching. Association for Supervision and Curriculum Development.

Scimago Institutions Ranking. (2018). Scimago journal \& country rank. https://www.scimagoir.com/

Selvaggi, T. (2016). Principal and literacy coach: Collaboration and goal alignment. The Delta Kappa Gamma Bulletin, 82(3), 28.

Shanklin, N. L. (2006, September). What are the characteristics of effective literacy coaching? Literacy Coaching Clearinghouse. https://files.eric.ed.gov/fulltext/ED530356.pdf

Society for the Advancement of Excellence in Education. (2009). Key factors to support literacy success in school-aged populations: A literature review. Canadian Education Statistics Council.

Still, R., Weir, L., \& Goldblatt, A. (2007). Creating learning partners: A facilitators' guide for training effective adult literacy tutors. Literacy Alberta.

Symonds, K. (2003). Literacy coaching: How school districts can support a long-term strategy in a short-term world. Bay Area School Reform Collaborative. https://files.eric.ed.gov/fulltext/ED477297.pdf

Toll, C. A. (2005). The literacy coach's survival guide: Essential questions and practical answers. International Reading Association.

Walpole, S., \& McKenna, M.C. (2004). The literacy coach's handbook: A guide to research-based practice. Guilford.

Walpole, S., \& McKenna, M.C. (2013). The literacy coach's handbook: A guide to research-based practice (2nd ed). Guilford.

\section{Author Biographies}

Dr. Peng Liu is an assistant professor in the Faculty of Education of University of Manitoba. His research interests include Indigenous leadership, effective leadership, educational change, educational policy, teacher professional development, and international and comparative education. Dr. Liu earned his doctorate degree from the Ontario Institute for Studies in Education at the University of Toronto. Dr. Liu has published articles in peer-reviewed journals including School Effectiveness and School Improvement, the Journal of Educational Administration, the International Journal of Leadership in Education, and International Studies in Educational Administration. He also serves as an associate editor for the International Journal of Comparative Education and Development.

Mr. Xuyang Li is a graduate student in the Faculty of Education at the University of Manitoba.

Ms. Zhuoma Ciren is a graduate student in the Faculty of Education at the University of Manitoba. 


\section{Appendix A}

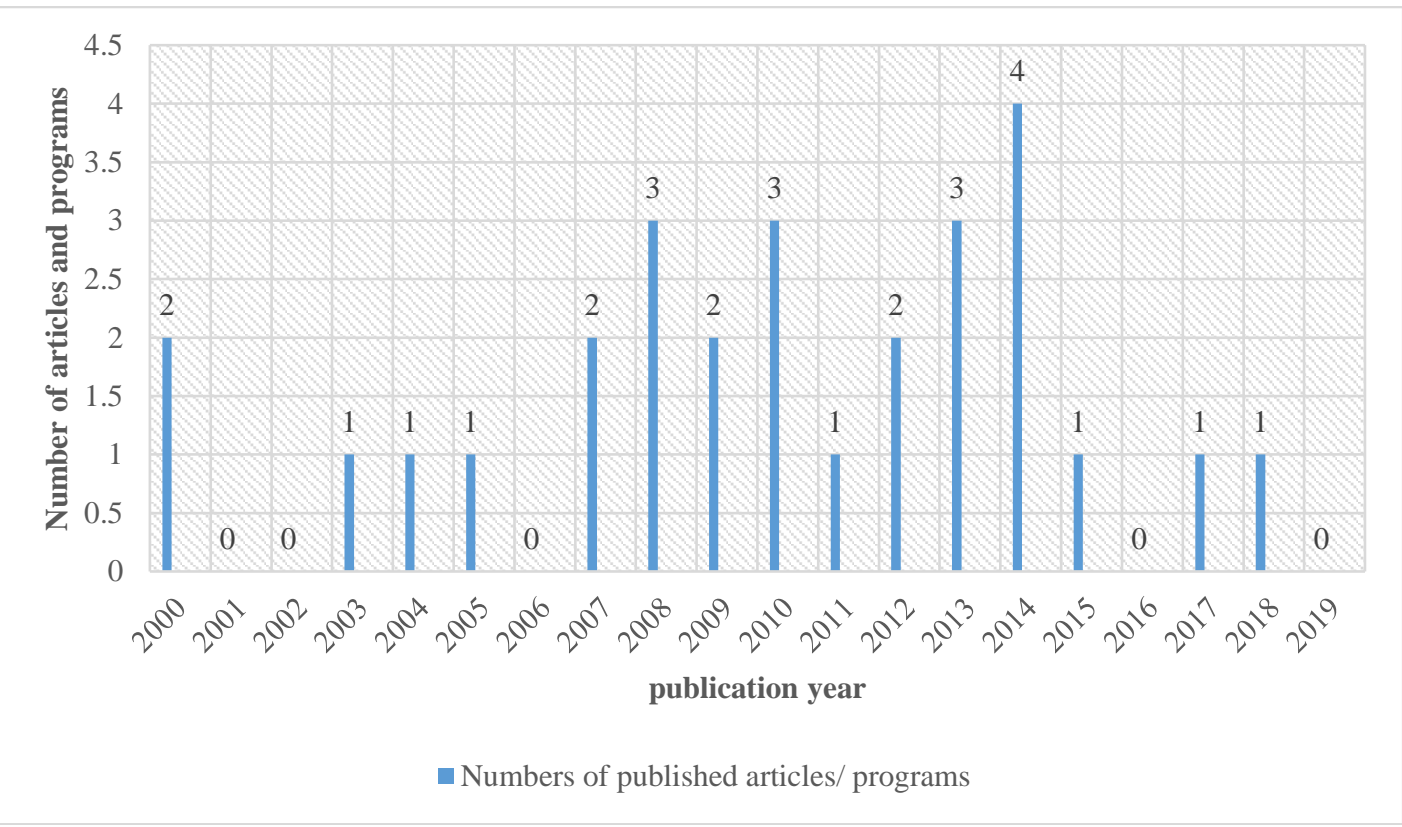

Figure 1. Number of Disseminated Articles and Program Documents on the Topic of Literacy Coaching since 2000 in Canada

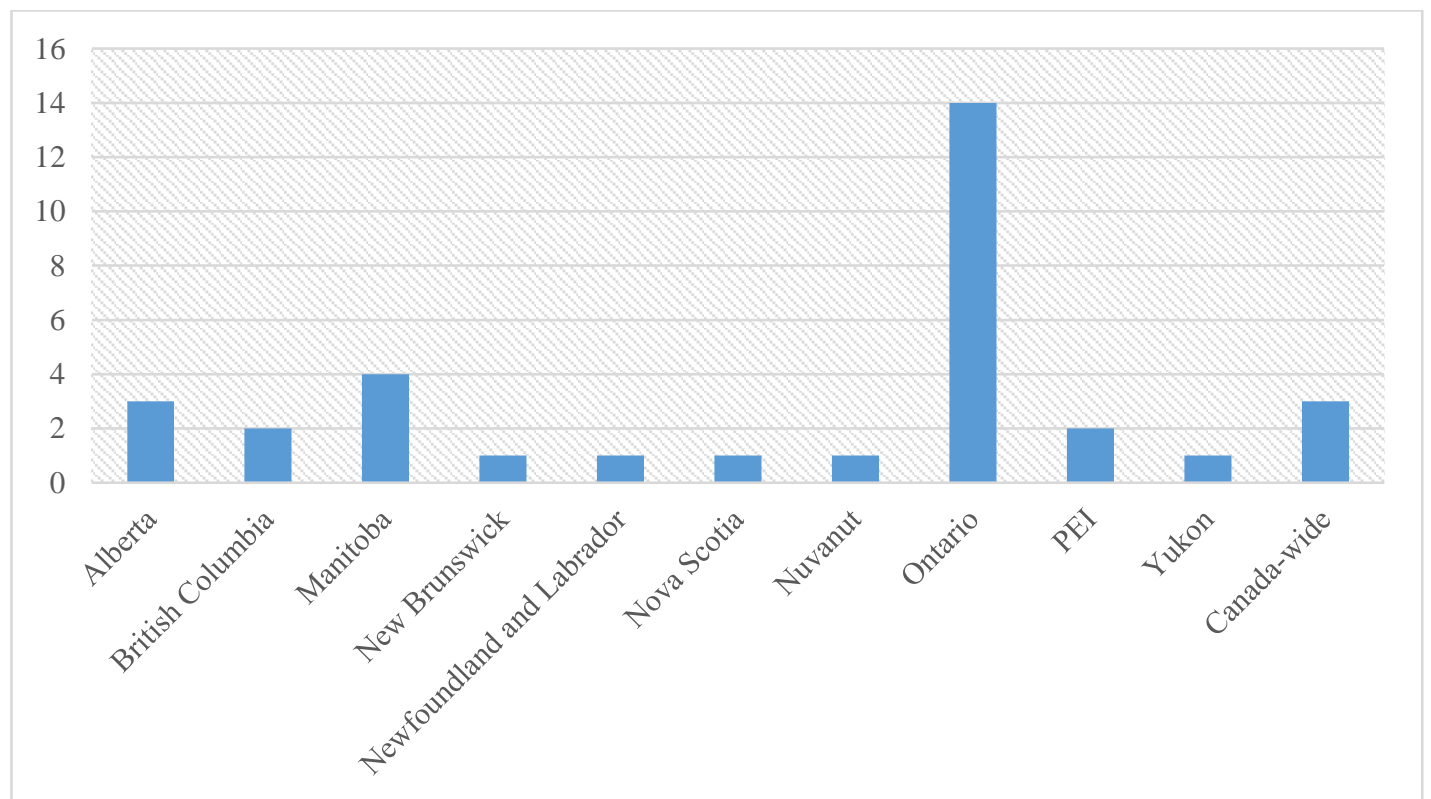

Figure 2. Number of Disseminated Articles and Program Documents on the Topic of Literacy Coaching by Province and Territory in Canada 


\section{Focal topics of research on literacy coaching in Canada}

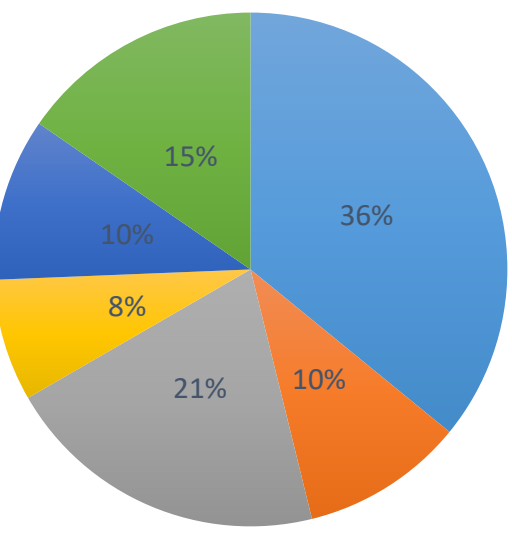

$$
\begin{aligned}
& \text { roles and responsibilities a barriers and challenges } \quad \text { suggestions and tips } \\
& \text {-identity and relationship } \quad \text { understanding and perception } \square \text { education and training }
\end{aligned}
$$

Figure 3. Focal Topics of Research on Literacy Coaching in Canada

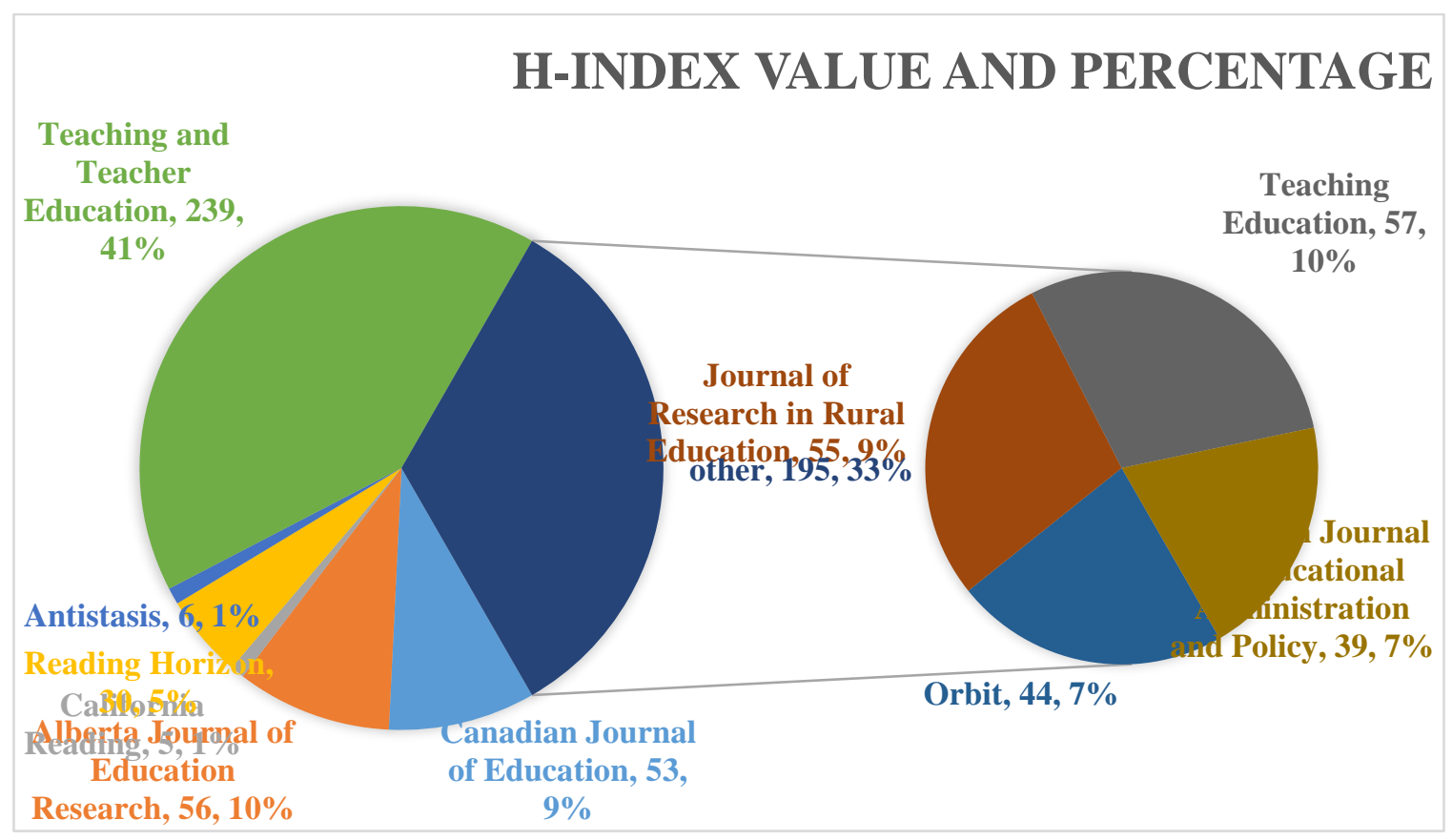

Figure 4. The Journals' H-index and Their Percentage of the Total H-index of All Journals 